\title{
PENGEMBANGAN PEMBELAJARAN PETA KONSEP DAN APLIKASI E- LEARNING MOODLE: UPAYA MENINGKATKAN KETUNTASAN BELAJAR DAN SIKAP POSITIF TERHADAP MATEMATIKA SISWA SMK SURAKARTA ${ }^{1)}$
}

\author{
Henny Ekana Chrisnawati, Ira Kurniawati, Yemi Kuswardi
}

\begin{abstract}
This main purpose of this research is developing a mind mapping model of learning with moodle e learning application to increase SMK's student mathematics achievement and positive attitudes towards of mathematics. In line with the objective of the research, so this research is $\mathrm{R}$ and $\mathrm{D}$ research model. This research aim to produce a learning devices and research instruments that comply a mind mapping model of learning with moodle e learning application. It used 4D procedur by Thiagarajan that comprised some phase, namely : Define, Design, Develop, and Disseminate

The subject of development research is XH class of SMK Warga Surakarta's students. The collection data methods, we used achievement test of students, validation sheet of all instruments research, and observation sheet of positives attitudes students of towards mathematics, observation sheet of management classroom by the teacher, students response sheet towards devices and the implementation of learning. To analyze the datas, we used quantitative descriptive analyze. The descriptive analyze used to describe achievement of learning outcomes from validator, that consist of mathemetics achievement, positives attitudes towards mathematics and students responses to mind mapping model of learning with moodle e learning application.

The result of this research has been developed the devices of learning and implementation of mind mapping model of learning with moodle e learning application. That is (1) the average of positives attitudes towards mathematics reliabilities is $79.2 \%$. It means the result of observations made both observers was credible and the instruments had a good category (2) the average of reliabilities of teacher's abilities to manage his classroom is $84.75 \%$. It means the result of observations made both observers was credible and the instruments had a good category. (3) the result of respons's students was unknown thal all aspects were above $70 \%$, exception was an aspect that related by classroom condition (3) the achievement tes that was developed from this research were valid instrument, have reliability indeks 0.77 and the average of sensitive indeks was 0.5051. It means that all instrument of learning can be used.
\end{abstract}

Kata Kunci : pembelajaran peta konsep, aplikasi e learning moodle, sikap positif siswa terhadap matematika, hasil belajar

\section{PENDAHULUAN}

Matematika merupakan salah satu program pembelajaran adaptif pada jenjang pendidikan SMK, selain bahasa Inggris, Fisika, Kimia, Biologi, Komputer dan Kewirausahaan. Disebutkan tujuan pembelajaran matematika di SMK dalam Peraturan Menteri Pendidikan Nasional Republik Indonesia Nomor 22 Tahun 2006 tentang Standar Isi diantaranya adalah agar peserta didik memiliki kemampuan seperti memahami konsep Matematika, menjelaskan keterkaitan antar konsep dan mengaplikasikan konsep atau algoritma, secara luwes, akurat, efisien, dan tepat, dalam pemecahan masalah dan menghargai kegunaan matematika dalam kehidupan, yaitu memiliki rasa ingin tahu, perhatian, dan minat dalam mempelajari matematika, serta sikap ulet dan percaya diri dalam 
pemecahan masalah. Di samping itu memberi kemampuan untuk menerapkan Matematika pada setiap program keahlian.

Kenyataan tersebut menunjukkan bahwa penguasaan materi matematika oleh siswa menjadi suatu keharusan yang tidak dapat ditawar lagi. Namun ironisnya, matematika menjadi salah satu mata pelajaran yang banyak dikeluhkan oleh sebagian besar siswa SMK. Dari hasil perbincangan dengan guru mata pelajaran matematika di SMK Warga Surakarta, diperoleh informasi tentang rendahnya minat siswa untuk melaksanakan remedial materi matematika yang belum tuntas sehingga mereka baru akan melaksanakan remedial saat akan kelulusan atau kenaikan kelas. Tidak mengherankan, mengingat karakteristik kegiatan belajar siswa SMK memang untuk mempersiapkan anak pada dunia kerja, beban belajar siswa SMK yang sangat padat, banyaknya kegiatan praktikum keahlian yang harus diselesaikan oleh siswa, serta adanya anggapan siswa terhadap mata pelajaran adaptif (termasuk Matematika) yang dirasakan kurang begitu penting bagi pekerjaan mereka kelak, sedangkan dalam standar isi di atas jelas tertuang bahwa salah satu tujuan pembelajaran matematika adalah siswa menghargai kegunaan matematika. Bahkan dalam penelitian Hobri ( 2002), disebutkan bahwa hampir tiap pembelajaran matematika, rata-rata $15 \%$ siswa SMK sekotatif Jember tidak mengikuti pelajaran. Rendahnya sikap positif siswa terhadap matematika tentunya juga menjadi masalah bagi guru, karena sikap terhadap matematika berkaitan dengan sikap suka atau tidak suka untuk ikut dalam kegiatan pemecahan masalah matematika.

Belajar matematika pada dasarnya merupakan proses yang diarahkan pada suatu tujuan, yakni kemampuan seseorang dalam memfungsionalkan materi matematika secara praktis maupaun secara konseptual. Secara konseptual artinya dapat mempelajari matematika lebih lanjut, sedangkan secara praktis artinya mampu menerapkan matematika pada bidang-bidang lain.

Belajar lebih dari sekedar mengingat. Siswa yang benar-benar mengerti dan mampu menerapkan pengetahuannya, harus berusaha memecahkan berbagai masalah yang dihadapinya, mencari sesuatu untuk dirinya sendiri dan bergelut dengan ideidenya. Menurut Soekahar (1992) menyatakan bahwa belajar matematika adalah belajar berkenaan dengan ide-ide, struktur-struktur yang dianut menurut aturan yang logis. Jadi dapat disimpulkan bahwa seseorang belajar matematika jika pada diri seseorang tersebut terjadi perubahan tingkah laku yang berkaitan dengan matematika, misal terjadi perubahan dari tidak tahu menjadi tahu dan mampu menerapkan dalam kehidupan nyata.

Salah satu prinsip penting psikologi pendidikan adalah guru tidak hanya memberi siswa pengetahuan dengan cara penyampaian informasi kepada siswa, namun siswalah yang seharusnya 
membangun pengetahuan dalam pikiran mereka sendiri dengan teman maupun fasilitas sumber belajar yang diberikan guru. Dalam proses pembelajaran guru berperan memberikan dukungan.

Sehubungan dengan pentingnya peranan matematika, maka sudah seharusnya segala permasalahan pada proses pembelajaran matematika ditangani dengan baik, termasuk didalamnya dengan memahami karakter dan banyaknya beban belajar siswa. Pendidik perlu mempersiapkan suatu model atau fasilitasi pembelajaran yang terprogram agar peserta didik mencapai ketuntasan belajar yang diharapkan dan mampu meningkatkan sikap positif terhadap matematika siswa.

Pembelajaran umum matematika, yang dirumuskan oleh National Council of Teachers of Matematics atau NCTM menggariskan, peserta didik harus mempelajari matematika melalui pemahaman dan aktif membangun pengetahuan baru dari pengalaman dan pengetahuan yang dimiliki sebelumnya. Untuk mewujudkan hal itu, dirumuskan lima tujuan umum pembelajaran matematika, yaitu: pertama, belajar untuk berkomunikasi (mathematical communication); kedua, belajar untuk bernalar (mathematical reasoning); ketiga, belajar untuk memecahkan masalah (mathematical problem solving); keempat, belajar untuk mengaitkan ide (mathematical connections); dan kelima, pembentukan sikap positif terhadap matematika (positive attitudes toward mathematics). Semua itu lazim disebut mathematical power (daya matematika).

Sebagai salah satu tujuan pendidikan matematika adalah pembentukan sikap siswa. Oleh karena itu, sudah sepatutnya dalam proses pembelajaran matematika perlu diperhatikan sikap siswa atau peserta didik terhadap matematika. Menurut Khalik , dalam Syahrul (2011), menjelaskan pentingnya sikap positif terhadap matematika ( positive attitudes toward mathematics ) dalam pembelajaran matematika, Mathematical attitudes is a very important affective factor in determining students' behavior in mathematical thinking and problem solving because students' attempts in mathematical thinking depend on how interested they are in problem solving or the lesson. Khalik menjelaskan bahwa sikap matematika adalah faktor afektif yang sangat penting dalam menentukan perilaku siswa dalam pemikiran matematika dan pemecahan masalah karena upaya siswa dalam pemikiran matematis tergantung pada bagaimana mereka tertarik dalam pemecahan masalah atau pelajaran. Bagaimana seorang siswa dapat berhasil dalam mata pelajaran matematika, jika tidak menunjukkan sikap berminat, sikap tidak ingin tahu, tidak ingin ikut terlibat dalam kegiatan pemecahan masalah matematika? Faktor afektif untuk menghargai pentingnya belajar matematika, ketertarikan dalam belajar dan kegiatan memecahkan masalah 
adalah salah satu faktor yang mempengaruhi prestasi belajar siswa.

Salah satu pertimbangan peneliti untuk mengurangi beban belajar siswa dalam hal waktu belajar, sulitnya belajar di luar jam tatap muka dengan guru karena terkendala sumber belajar, adalah dengan mencoba mengaplikasikan moodle dalam pembelajaran matematika. Moodle merupakan akronim dari Modular Object Oriented Dynamic Learning Environment . Moodle adalah sebuah nama untuk sebuah program aplikasi yang dapat merubah sebuah media pembelajaran ke dalam bentuk web. Dengan konsep ini sistim belajar mengajar akan tidak terbatas ruang dan waktu. Siswa dapat belajar dalam ruang belajar digital, dimana siswa dapat belajar dari mana saja, dapat mengakses materi kapan saja. Dengan menggunakan moodle dapat membangun sistem dengan konsep elearning ataupun pembelajaran jarak jauh. Dengan fasilitas yang tersedia pada moodle seorang pengajar bisa melengkapi materi bahan ajarnya dengan menambahkan forum dikusi online, chatting tes yang memungkinkan pembelajaran bisa dilaksanakan secara menarik dan interaktif .

Menurut Martin Dougiamaa, dalam Isma Nita di edukasi.kompasiana.com,

"I'm committed to continuing my work on Moodle and on keeping it Open and Free. I have a deeply-held belief in the importance of unrestricted education and empowered teaching, and Moodle is the main way I can contribute to the realisation of these ideals." - Martin Dougiamas.
Kutipan di atas merupakan ucapan Martin Dougiamas sang pencipta Moodle. Martin Dougiamas sendiri merupakan seorang doktor di bidang pendidikan dengan latar belakang ilmu komputer yang baik. Melalui filosofi Social Constructionist Pedagogy, Martin mencoba menciptakan moodle sebagai salah satu Learning Management System yang berbasis open source. Ada 4 hal utama yang terkandung dalam filososofi social constructionist pedagogy yang dikemukakan oleh Martin, yaitu:

1) Constructivism. Pandangan ini berpendapat bahwa manusia secara aktif membangun (construct) pengetahuan baru saat berinteraksi dengan lingkungannya.

2) Constructionism. Constructionism menyatakan bahwa belajar sangat efektif dilakukan pada saat menjelaskan suatu konsep/hal bagi orang lain dalam rangka membangun pengalaman (experience).

3) Social Constructivism. Social Constructivism akan memperluas ide-ide di atas ke dalam sebuah kelompok (social group), secara kolaboratif menciptakan budaya kecil dalam membagi artifacts dengan membagi meanings.

4) Connected and Separate. Ide ini melihat lebih dalam berbagai motivasi dari individu dalam sebuah diskusi. Perilaku yang terpisah (separated behaviour) ketika seseorang cenderung untuk mempertahankan ide masing-masing menggunakan logika untuk menemukan celah pada ide yang berseberangan dengannya. Perilaku 
terhubung (connected behaviour) merupakan pendekatan yang lebih empatik dalam menerima subjektivitas, mencoba untuk mendengarkan dan bertanya sesuatu sebagai upaya untuk memahami sudut pandang yang berbeda.

Karakteristik pada moodle inilah yang dapat membuat siswa dapat difasilitasi oleh guru untuk “ belajar". Siswa dapat menyelesaikan tugas-tugasnya dari fasilitas moodle bersama teman. Terbentuknya sikap social contructivism, dapat membuat siswa lebih nyaman dalam belajar.

Pada penelitian ini, peneliti juga akan menggunakan peta konsep pada saat pembelajaran di kelas, karena penggunaan aplikasi Moodle tanpa siswa tahu keterkaitan dan kegunaan belajar maka siswa akan tetap memiliki anggapan yang terpisah-pisah akan konsep matematika, apalagi jika mata pelajaran tersebut diampu oleh guru yang berbeda-beda. Dengan demikian mengetahui hubungan dari konsep matematika, keterkaitan antar konsep sehingga siswa mampu memahami konsep di pembelajaran matematika secara utuh sehingga menimbulkan sikap positif yang baik terhadap matematika.

Peta konsep atau peta pembelajaran adalah cara dinamik untuk menangkap butirbutir pokok informasi. Menurut Novak, J.D \& Grown D.B dalam Ratna Wilis Dahar (1989) , memberikan gambaran peta konsep seperti peta jalan. Konsep digambarkan sebagai nama tempat sedang hubungan digambarkan sebagai jalan, maksudnya adalah hubungan di antara konsep seperti rute perjalanan antar tempat. Dan peta konsep menurut Morarie dalam Kartika Budi (1990), adalah peta (jaringan, diagram) yang memuat konsep-konsep dan hubungannya dan menyatakan hubungan hierarkis antara konsep yang satu dengan konsep yang lain. Peta konsep merupakan ilustrasi grafis konkret yang mengindikasikan bagaimana sebuah konsep tunggal dihubungkan ke konsep-konsep lain pada kategori yang sama. Dalam peta konsep diberikan gambaran nyata keterkaitan konsep untuk membantu siswa mengorganisasikan informasi sebelum informasi tersebut dipelajari. Pendayagunaan model belajar peta konsep gagasan Novak dalam Ratna Wilis Dahar (1989) ini bertujuan untuk membimbing anak didik belajar tentang bagaimana cara belajar bermakna. Bahwa belajar bermakna akan terjadi bilamana konsep-konsep baru yang dipelajari siswa dikaitkan dengan konsep-konsep yang sudah ada di dalam struktur kognitifnya. Lebih jauh, dapat diartikan pula bahwa belajar bermakna akan dapat berlangsung terus bila di dalam struktur kognitif itu semua konsep diupayakan saling berkaitan satu sama lain.

Dari kajian di atas, dapat disimpulkan pemetaan konsep adalah cara penyajian konsep dalam bentuk kaitan atau hubungan antar konsep sehingga seseorang dapat melihat keterpaduan antar konsep tersebut, diharapkan dengan membuat peta konsep, pembelajaran menjadi lebih bermakna, khususnya materi matematika, karena siswa 
telah mampu membuat kaitan dari konsep baru ataupun konsep yang telah dimilikinya secara terstruktur

Dari kajian di atas, peneliti akan mengembangkan model dan perangkat pembelajaran yang menerapkan peta konsep dan aplikasi e learning moodle dalam upaya meningkatkan hasil belajar siswa ( ketuntasan belajar) dan sikap positif terhadap matematika ( positive attitudes toward mathematics ) siswa SMK Surakarta.

\section{METODE PENELITIAN}

Penelitian ini merupakan suatu penelitian pengembangan. Karena penelitian ini bertujuan untuk menghasilkan suatu perangkat pembelajaran dan instrumen penelitian maka prosedur pengembangan perangkat yang dikembangkan oleh Thiagarajan, yang meliputi tahap-tahap
Define (Pendefinisian), Design (Perencanaan), Develop (Pengembangan), dan Disseminate (Pendesiminasian). Gambar 1 menunjukkan rincian Proses pengembangan perangkat pembelajaran yang meliputi empat tahap, yaitu tahap Define, Design, Develop, dan Disseminate.

Subyek yang digunakan untuk pengembangan perangkat pembelajaran adalah siswa SMK Warga Surakarta kelas $\mathrm{XH}$ yang terdiri atas 43 siswa. Untuk memperoleh data yang diperlukan digunakan teknik tes, lembar pengamatan sikap positif siswa terhadap matematika, lembar pengamatan kemampuan guru dalam mengelola kelas dan lembar respon siswa terhadap pembelajaran dan perangkatnya. 


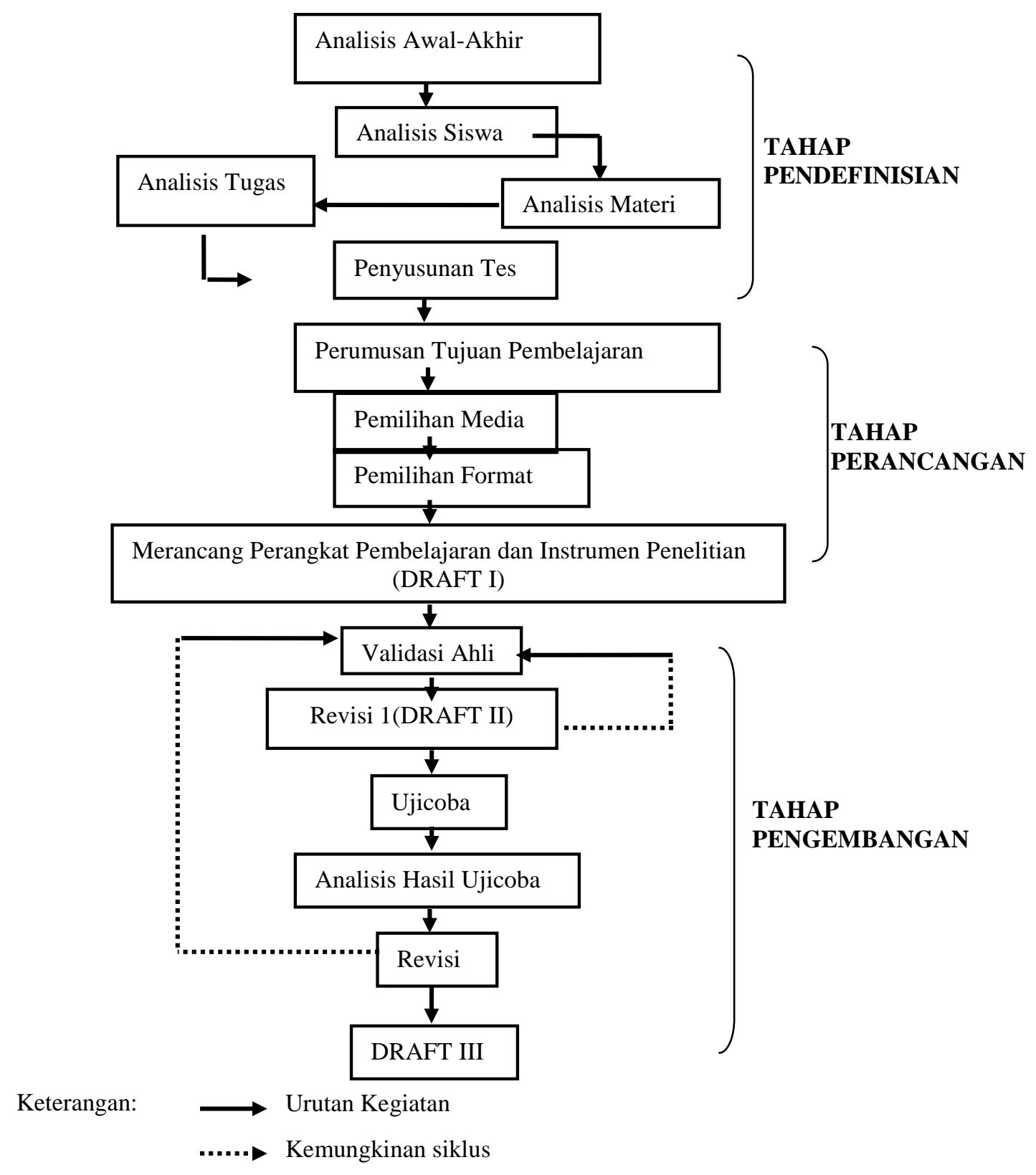

Diamond (dalam Mudoffir, 1987) kegiatan pembelajaran dapat dilihat dari berpendapat bahwa keefektifan pembelajaran juga dapat diukur dengan melihat minat siswa terhadap kegiatan pembelajaran. Minat siswa terhadap respon siswa terhadap pembelajaran yang berlangsung. Dalam penelitian ini indikator pada aspek respon siswa adalah: (1) senang tidaknya siswa terhadap komponen 
pembelajaran (2) Ketertarikan siswa terhadap modul yang diberikan (3 ) Ketertarikan siswa untuk mengikuti pembelajaran dengan model pembelajaran peta konsep dengan aplikasi moodle (4) Jelas tidaknya bimbingan yang diberikan guru (5) Senang tidaknya siswa terhadap kegiatan-kegiatan selama pembelajaran.

Sedangkan tes hasil belajar yang penulis susun tergolong tes beracuan patokan (PAP).. Pertimbangan dasar dalam menilai penguasaan materi pada tes beracuan patokan adalah sejauh mana butir soal dapat mengukur efek pembelajaran, sehingga dalam analisis butir soal ini penulis memfokuskan kualitas butir soal pada tingkat sensitivitas soal, validitas soal dan reliabilitas.

Sedangkan tingkat reliabilitas dari instrumen observasi sikap positif terhadap matematika siswa dihitung menggunakan analisis statistik percentage of agreement.

Begitupun untuk data kemampuan guru dalam pengelolaan kelas, untuk menghitung tingkat reliabilitas digunakan analisis statistik percentage of agreement. Selanjutnya nilai rata-rata tersebut dikonversikan dengan kategori pembelajaran peta konsep dengan aplikasi moodle dengan menggunakan kriteria: tidak bik (1,00 $1,49)$, kurang baik $(1,50-2,49)$, baik $(2,50$ - 3,49), dan sangat baik $(3,50-4,00)$ (Adopsi Alhadad, 2002).

Kemampuan guru dalam mengelola pembelajaran dikatakan efektif apabila ratarata nilai setiap aspek yang diamati dalam mengelola pembelajaran berada pada interval 2,50 - 4,00 dengan syarat hasil pengamatan pada kegiatan inti untuk setiap aspek yang diamati mencapai kategori minimal baik.

\section{HASIL DAN PEMBAHASAN}

Perangkat pembelajaran yang telah dikembangkan dalam penelitian ini adalah (1) silabus, (2) RPP, (3) Modul dan lembar kegiatan, (4) soal tes hasi belajar siswa materi persamaan dan pertidaksamaan linear mapun kuadrat.

\section{Tahap define}

\section{a. Analisis Awal-Akhir}

Berdasarkan teori belajar tersebut, bahwa belajar matematika pada dasarnya merupakan proses yang diarahkan pada suatu tujuan, yakni kemampuan seseorang dalam memfungsionalkan materi matematika secara praktis maupaun secara konseptual. Secara konseptual artinya dapat mempelajari matematika lebih lanjut, sedangkan secara praktis artinya mampu menerapkan matematika pada bidang-bidang lain. Pengertian yang terkandung dari teori tersebut adalah perlunya kebermaknaan matematika bagi siswa. Namun demikian, perlu kiranya guru juga memahami waktu efektif belajar siswa SMK yang sangat padat. Untuk itu perlu kiranya dipikirkan bagaimana agar siswa dapat belajar di luar jam sekolah. Sehinga dengan memanfaatkan e learning Moodle dalam kegiatan belajar mengajar dapat memfasilitasi siswa untuk belajar di luar kelas dan di luar jam sekolah. 


\section{b. Analisis Siswa}

Siswa yang dianalisis dalam penelitian ini adalah siswa SMK Warga Surakarta kelas XH semester 1. Berdasarkan informasi dari pihak sekolah, siswa kelas tersebut memiliki input rataan nilai UAN matematika yang lebih rendah dibanding kelas lain. Dalam analisis kemampuan matematika siswa, bahwasanya siswa sudah pernah mendapatkan materi-materi penunjang yang diperlukan untuk mempelajari materi tersebut, seperti operasi bilangan bulat maupun bilangan real, operasi hitung aljabar serta persamaan linear satu variabel.

Berdasar hal tersebut maka pembelajaran dengan model pembelajaran peta konsep dengan menggunakan e learning Moodle cocok untuk diberikan pada siswa SMK Warga Surakarta, karena dasar/prasyarat untuk materi Persamaan dan pertidaksamaan Linier Satu Variabel, Sistem Persamaan Linier Dua Variabel dan Persamaan serta Pertidaksamaan Kuadrat sudah dimiliki siswa sehingga dalam penyusunan peta konsep mampu dilakukan untuk keterkaitannya.

\section{c. Analisis Materi}

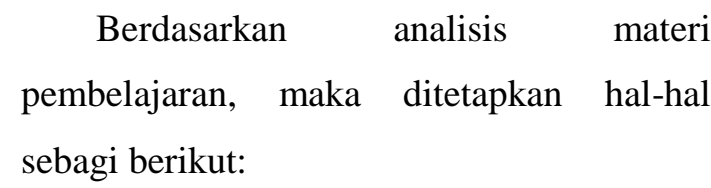

- Materi : ( 1) Persamaan Linier Satu Variabel (2) Pertidaksamaan Linier Satu variabel (3) Sistem Persamaan Linier Dua Variabel (4) Persamaan Kuadrat dan (5) Pertidaksamaan Kuadrat
- Prasyarat : Operasi hitung aljabar, sistem bilangan real

\section{d. Analisis Tugas}

Analisis tugas yang telah dilakukan pada materi Persamaan dan Pertidaksamaan Linear maupun Kuadrat adalah siswa mampu memecahkan masalah yang berkaitan dengan sistem persamaan dan pertidaksamaan linier dan kuadrat

\section{Tahap Perencanaan (Design)}

Setelah dilakukan analisis materi dan perumusan indikator, maka disusunlah perangkat pembelajaran (modul, silabus, rencana pelaksanaan pembelajaran/RPP) dan tes hasil belajar yang hasilnya disebut draft 1.

\section{a. Penyusunan Tes Hasil Belajar}

Dasar penyusunan tes adalah analisis materi, analisis tugas, dan perumusan indikator. Tes yang dimaksud adalah tes hasil belajar materi Persamaan dan Pertidaksamaan Linear dan Persamaan serta Pertidaksamaan Kuadrat. Pengembangan tes hasil belajar didahului dengan membuat kisikisi dan acuan penskoran butir soal.

\section{b. Pemilihan Format}

Format dari perangkat pembelajaran yang dikembangkan meliputi modul, silabus, dan rencana pelaksanaan pembelajaran (RPP). Sedangkan untuk mengungkapkan proses pembelajaran, maka diperlukan instrumen pengamatan sikap positif terhadap matematika siswa, instrumen pengamatan kemampuan mengelola pembelajaran, dan angket respon siswa terhadap kegiatan pembelajaran dan perangkatnya. 


\section{c. Pemilihan Media}

Berdasarkan analisis materi pada materi Persamaan dan Pertidaksamaan Linear maupun Kuadrat dan berdasar pada karakteristik siswa yang telah berada pada tahap perkembangan operasional formal maka didesain modul sebagai media pembelajaran, lembar kegiatan siswa dalam moodle.

\section{d. Desain Awal}

Hasil rancangan awal perangkat pembelajaran pada tahap ini adalah modul, RPP dan silabus. Modul digunakan siswa sebagai panduan dalam belajar. RPP merupakan rencana pelaksanaan pembelajaran yang didalamnya memuat kompetensi dasar, indikator, materi pembelajaran untuk pertemuan 1 sampai 8 model pembelajaran, sumber belajar, dan langkah-langkah pembelajaran pada pertemuan 1 hingga 8 . Lembar kegiatan berisi ringkasan materi dan kegiatankegiatan yang harus diselesaikan mahasiswa baik secara individu. Lembar kegiatan tersebut terdapat pada moodle, dengan pertimbangan siswa dapat belajar dengan ringkasan-ringkasan materi yang ada sebelum siswa masuk ke lembar soal untuk menyelesaikan tugas-tugasnya.

\section{Deskripsi Tahap Pengembangan (Develop)}

Setelah draf I (modul, RPP, lembar kegiatan, dan tes hasil belajar) dibuat, dilanjutkan ke tahap pengembangan yaitu penyempurnaan draft I. langkah-langkah yang dilakukan adalah sebagai berikut: penilaian (validasi) draft I oleh para ahli pendidikan matematika, hasil revisi draft I ini akan menghasilkan draft II. Draft II yang dihasilkan kemudian diujicobakan secara terbatas. Hasil dari uji coba terbatas kemudian dianalisis. Berdasar analisis hasil ujicoba, draft II kemudian direvisi. Hasil revisi draft II ini akan menghasilkan naskah final (draft III).

\section{a. Tes Hasil Belajar}

Untuk mendapatkan draft II dari tes hasil belajar yang akan digunakan untuk uji coba terbatas, maka saran para ahli pendidikan matematika (validator) sangat diperlukan sebagai bahan pertimbangan untuk merevisi tes hasil belajar. Dalam melakukan validasi ini terdapat 4 orang validator. Hasil penilaian para validator butir 1 2, 3 dan 4 layak dapat digunakan dengan sedikit perbaikan. Perbaikan yang dilakukan adalah terhadap bahasa, materi dan penyesuaian waktu yang digunakan untuk mengerjakan.

\section{b. Modul, RPP, dan Lembar Kegiatan}

Bebarapa masukan dari validator tentang draft I modul, RPP dan LKdapat dilihat pada Tabel 1 .

Tabel.1.

\begin{tabular}{|l|l|l|}
\hline Sebelum Revisi & Sesudah Revisi/Perbaikan & \\
\hline $\begin{array}{l}\text { Kesesuaian gambar yang kurang sesuai } \\
\text { dengan bentuk nyatanya }\end{array}$ & $\begin{array}{l}\text { Gambar sudah disesuaikan dengan keadaan } \\
\text { "nyatanya" } \\
\begin{array}{l}\text { Alokasi waktu untuk masing-masing } \\
\text { kegiatan pembelajaran di RPP }\end{array}\end{array}$ & Sudah dirinci alokasi waktunya \\
\hline
\end{tabular}


Bahan apersepsi perlu diperjelas

Tujuan afektif di RPP perlu disesuaikan dengan sikap positif siswa terhadap matematika

Masalah bahasa/ tata tulis

Variansi soal perlu diperhatikan

\section{Instrumen Penelitian (Lembar}

Pengamatan Sikap Positif Terhadap

Matematika Siswa, Lembar Pengamatan

Kemampuan Guru dalam Mengelola

Pembelajaran, dan angket Respon Siswa)

Untuk pengembangan perangkat penelitian, peneliti juga mendapatkan masukan dari validator sebagai pertimbangan penyusunan instrumen penelitian. Terdapat beberapa masukan dari validator. Salah satunya adalah merevisi lembar pengamatan sikap positif siswa terhadap matematika.

\section{a. Analisis dan Interpretasi Data Hasil Uji}

\section{Coba}

Analisis deskriptif data dilakukan untuk menganalisa data aktivitas untuk melihat
Sudah diberikan bahan untuk apersepsi

Tujuan afektif pembelajaran sudah disesuaikan

Sudah dilakukan revisi atas bahas/ tata tulis di modul/LK

Memberikan soal yang lebih variatif

sikap positif terhadap matematika siswa selama kegiatan pembelajaran dengan model pembelajaran peta konsep dengan aplikasi e Learning Moodle, kemampuan guru dalam mengelola pembelajaran, respon siswa terhadap pembelajaran, dan hasil belajar siswa selama mengikuti kegiatan pembelajaran. Tujuan dari analisis data hasil uji coba ini untuk melihat kelemahan dan kebaikan perangkat pembelajaran dan instrumen penelitian yang diujicobakan. Kelemahan perangkat pembelajaran dan instrumen penelitian yang diperoleh, diperlukan sebagai bahan masukan untuk merevisi draft II. Berikut ini hasil analisis dan interpretasi data hasil uji coba.

Tabel 2. Hasil Pengamatan Sikap Positif Siswa terhadap Matematika

\begin{tabular}{|c|c|c|c|c|c|c|c|c|}
\hline \multicolumn{7}{|c|}{ INDIKATOR SIKAP POSITIF TERHADAP MATEMATIKA } \\
\hline $\mathbf{1}$ & $\mathbf{2}$ & $\mathbf{3}$ & $\mathbf{4}$ & $\mathbf{5}$ & $\mathbf{6}$ & $\mathbf{7}$ & $\mathbf{8}$ & $\mathbf{9}$ \\
\hline 36 & 43 & 76 & 19 & 8 & 27 & 38 & 22 & 19 \\
\hline 34 & 44 & 87 & 19 & 14 & 23 & 32 & 12 & 22 \\
\hline 33 & 49 & 82 & 30 & 7 & 19 & 34 & 22 & 11 \\
\hline 39 & 41 & 98 & 13 & 16 & 25 & 24 & 22 & 10 \\
\hline 31 & 29 & 98 & 22 & 32 & 18 & 36 & 12 & 10 \\
\hline 32 & 29 & 84 & 15 & 35 & 24 & 37 & 17 & 15 \\
\hline 205 & 235 & 525 & 118 & 112 & 136 & 201 & 107 & 87 \\
\hline $11,9 \%$ & $13,6 \%$ & $30,4 \%$ & $6,8 \%$ & $6,5 \%$ & $7,9 \%$ & $11,6 \%$ & $6,2 \%$ & $5,0 \%$ \\
\hline
\end{tabular}

Pada Tabel 2 nampak bahwa aktivitas siswa mengerjakan worksheet yang diberikan adalah aktivitas yang paling banyak dilakukan siswa $(30,4 \%)$. Sedangkan perhitungan rata-rata reliabilitas instrumen sikap positif siswa terhadap matematika adalah $79.6 \% \%$, artinya hasil pengamatan yang dilakukan kedua pengamat dapat dipercaya dan instrumen yang digunakan berkategori baik. 
Dari hasil pengamatan penelitian, ratarata setiap aspek yang diamati dalam mengelola pembelajaran selama delapan kali pertemuan berkisar antara 2,7 - 3,1 sehingga kemampuan guru dalam mengelola pembelajaran termasuk dalam kategori baik. Hanya pada kategori menjelaskan aktivitas yang akan dilakukan siswa pada saat akan berlangsungnya kegiatan pembelajaran dalam kategori cukup. Ini dikarenakan guru sering lupa menyampaikannya dan menganggap siswa sudah terbiasa mengikuti kegiatan pembelajaran yang akan dilaksanakan karena guru sudah membuat pengaturan atas setting kelasnya. Dengan menggunakan rumus percentage of agrrement diperoleh reliabilitas instrumen pengamatan kemampuan guru dalam mengelola pembelajaran pada masingmasing pertemuan adalah sebagaimana Tabel 3. Sedangkan Ringkasan hasil respon siswa untuk masing-masing aspek dapat dilihat pada Tabel 4.

Tabel 3.

\begin{tabular}{|l|l|l|l|l|l|l|l|l|}
\hline & \multicolumn{9}{|l|}{ Pertemuan } \\
\hline $\begin{array}{l}\text { Instrumen Pengamatan Kemampuan } \\
\text { Guru dalam Mengelola Pembelajaran }\end{array}$ & $\mathbf{1}$ & $\mathbf{2}$ & $\mathbf{3}$ & $\mathbf{4}$ & $\mathbf{5}$ & $\mathbf{6}$ & $\mathbf{7}$ & $\mathbf{8}$ \\
\hline Reliabilitas & 81 & 81 & 88 & 88 & 81 & 81 & 81 & 94 \\
\hline Rataan reliabilitas & $84.375 \%$ &
\end{tabular}

Tabel 4. Ringkasan hasil respon siswa untuk masing-masing aspek.

\begin{tabular}{|l|l|c|l|}
\hline No. & \multicolumn{1}{|c|}{ Keterangan } & \multicolumn{1}{|c|}{ Rata-Rata(\%) } & \multicolumn{1}{|c|}{ Respon } \\
\hline 1 & Respon terhadap komponen kegiatan mengajar & 86.3 & Senang \\
2 & Respon terhadap kegiatan belajar & 76.7 & Tidak kesulitan \\
3 & Respon untuk melakukan diskusi kelas & 60.47 & Tidak kesulitan \\
4 & Respon akan kemanfaatan bagi kemajuan siswa model & 74.72 & Ada kemajuan \\
5 & Ketertarikan dan kemanfaatan model mon & Tertarik \& \\
& pembelajaran peta konsep dengan aplikasi e Learning & & manfaat \\
& Moodle & & \\
6 & Respon terhadap bahan ajar yang ada di e learning & 74.47 & Senang \\
7 & Bahasa di lembar kegiatan & 76.7 & Mengerti \\
8 & Kejelasan urutan kerja lembar kegiatan & 60.4 & Baik \\
9 & Variasi dan tingkat kesulitan soal pada LK/modul & 4,74 & Baik \\
10 & Interaksi siswa dengan e learning moodle & & \\
\hline
\end{tabular}

Pada tabel 4 dapat disimpulkan bahwa respon siswa adalah positif. Berarti instrumen angkat respon siswa dapat digunakan untuk penelitian selanjutnya.

\section{Hasil Tes Belajar Siswa}

Dari hasil tes, tampak bahwa penerapan model pembelajaran dengan peta konsep dan aplikasi e learning Moodle untuk mengajarkan materi Persamaan dan
Pertidaksamaan Linear maupun Kuadrat dapat dikatakan berhasil, karena banyaknya siswa yang mencapai nilai di atas 60 sebesar 33 anak dari 43 anak atau $76.74 \%$. Hasil ini juga tampak dari peningkatan sikap positif siswa terhadap matematika baik saat kegiatan pembelajaran di kelas maupun interaksinya di elearning moodle serta jumlah kehadiran tatap muka siswa dalam 
pembelajaran yang baik. Dari hasil analisis butir soal, diperoleh sensitivitas tiap butir soal.

Tabel 5.

\begin{tabular}{|c|c|c|}
\hline Nomor Soal & Sensitivitas & Klasifikasi \\
\hline 1 & 0.35 & Peka \\
2 & 0.56 & Peka \\
3 & 0.60 & Peka \\
4 & 0.50 & Peka \\
\hline
\end{tabular}

Berdasarkan Tabel 5, ditunjukkan silabus, modul, lembar kegiatan, dan rencana bahwa semua butir tes hasil belajar pelaksanaan pembelajaran serta dihasilkan sensitivitasnya $\geq 0.30$ maka semua butir tes hasil belajar termasuk dalam kategori peka/sensitive, sehingga dapat disimpulkan bahwa semua butir tes hasil belajar dapat digunakan untuk mengukur penguasaan siswa terhadap materi Persamaan maupun Pertidaksamaan Linier ataupun Kuadrat. Sedangkan untuk koefisien reliabilitas instrumen tes diperoleh $\alpha=0.77$, maka dapat disimpulkan bahwa tes hasil belajar memiliki reliabilitas tinggi. Hal ini berarti tes hasil belajar dapat digunakan untuk mengukur penguasaan siswa terhadap materi persamaan dan pertidaksamaan linear maupun kuadrat. Jadi. dapat disimpulkan bahwa tes hasil belajar yang dikembangkan merupakan instrumen yang valid, reliabel dan sensitif maka instrumen ini dapat digunakan untuk penelitian selanjutnya

\section{SIMPULAN DAN SARAN}

Berdasarkan hasil analisis diperoleh simpulan sebagai berikut (1) Dengan menggunakan metoode pengembangan perangkat dari model Thiagarajan dihasilkan perangkat pembelajaran yang meliputi instrumen penelitian yang berupa tes hasil belajar, lembar pengamatan sikap positif siswa terhadap matematika, lembar pengamatan pengelolaan pembelajaran, dan angket respon siswa. (2) Merujuk pada kriteria keefektifan yang telah disampaikan pada Bab III, disimpulkan bahwa pembelajaran dengan peta konsep dan aplikasi e learning moodle efektif untuk mengajarkan matematika pada materi persamaan dan pertidaksamaan linear maupun kuadrat. (3) Hasil analisis sikap positif siswa terhadap matematika, bahwa antusias siswa mengerjakan lembar kerja yang diberikan adalah aktivitas yang paling banyak dilakukan siswa, begitupun respon saat pembelajaran matematika dimulai atau saat guru melakukan kegiatan pendahuluan, pemanasan berpikir, apersepsi juga tinggi dan kegiatan/usaha untuk bertanya tentang hal-hal yang kurang dimengerti. (4) Hasil analisis kemampuan guru dalam pengelolaan kelas, rata-rata setiap aspek yang diamati dalam mengelola pembelajaran selama delapan kali pertemuan berkisar antara 2,7 3,1 sehingga kemampuan guru dalam 
mengelola pembelajaran termasuk dalam kategori baik (5) Hasil analisis tes hasil belajar siswa, bahwa dengan penerapan model pembelajaran dengan peta konsep dan aplikasi e learning Moodle untuk mengajarkan materi Persamaan dan Pertidaksamaan Linear maupun Kuadrat, $76.74 \%$ siswa mencapai nilai di atas 60. (6) Respon siswa terhadap perangkat pembelajaran dan pembelajaran dengan pembelajaran dengan peta konsep dan aplikasi e learning moodle dan perangkat pembelajaran adalah positif karena persentase terbesar dari rata-rata persentase setiap indikator dari angket respon siswa berada dalam kategori senang, berminat, tidak kesulitan, tertarik, paham, baik, dan jelas.

Berdasarkan hasil penelitian in, peneliti memberikan saran-saran sebagai berikut perangkat pembelajaran pembelajaran matematika dengan peta konsep dan aplikasi e learning moodle dan perangkat pembelajaran dan instrumen penelitian yang dihasilkan valid dan reliabel sehingga baik perangkat pembelajaran maupun intrumen penelitian ini dapat dijadikan sebagai gambaran untuk penelitian lain pada topik ataupun situasi kelas yang berbeda dan adalah penting bagi guru untuk mempertimbangkan sikap positif siswa terhadap matematika untuk meningkatkan hasil belajar siswa.

\section{DAFTAR PUSTAKA}

Alhadad, Syarifah F. 2002. Model Pembelajaran Interaktif dalam Pembelajaran Perbandingan di SLTP Khatijah Surabaya. Tesis. PPs Universitas Negeri Surabaya.

Depdiknas (2006). Permendiknas Nomor 22 Tahun 2006 Tentang Standar Isi Sekolah Menengah Atas. Jakarta: Depdiknas.

Endang Mulyatiningsih. 2011. Metode Penelitian Terapan Bidang Pendidikan. Yogyakarta: Alfabeta, CV

Hobri. 2002. Efektifitas Pelaksanaan Pendidikan Sistem Ganda di SMK SeKotatit Jember. Jember: FKIP Universitas Jember

Isma Nita. 2011. Moodle [ on line] dalam http:// edukasi.kompasiana.com. diambil 20 Oktober 2012

Kartika Budi.1990. Peta dan Pemetaan Konsep Serta Peranannya dalam Kegiatan Belajar IPA ( Sains). Yogyakarta : Widya Darma

Mudhofir. 1987. Teknologi Instruksional. Bandung : Remaja Rosdakarya

Ratna Wilis Dahar. 1989. Teori-teori Belajar. Jakarta : Erlangga

Syahrul. 2011. Sikap Matematika ( Mathematics Attitudes) dalam http://sokratesfilsafatilmu.blogspot.com/2011/01/sika p-matematika. html

Thiagarajan, S \& Semmel, D. S \& Semmel, M. I. 1974. Instructional Development for Training Teacher of Expentional Children. Bloomington: Indiana University. 